\title{
MENINGKATKAN HASIL BELAJAR MATEMATIKA DENGAN PENERAPAN MODEL PEMBELAJARAN KOOPERATIF TIPE NUMBERED HEADS TOGETHER (NHT)
}

\author{
Rainita Fatubun dan Purwati \\ Universitas Papua, Jalan Gunung Salju, Manokwari Papua Barat Indonesia \\ Email:p.purwati@unipa.ac.id
}

\begin{abstract}
This study aims to improve student learning outcomes on the subject of equations and quadratic inequalities using cooperative model of NHT type. This research is a Classroom Action Research, using Kemmis and Taggart model, which is implemented in three cycles. Data were observed each cycle through learning result test, student and teacher observation, and interview. The data obtained are then analyzed through: data reduction, data presentation and conclusion. The results showed that the application of NHT, the type of cooperative model can improve students' mathematics learning outcomes, especially on the subject of equations and quadratic inequalities.
\end{abstract}

Keywords: Classroom Action Research, Cooperative Model, Numbered Heads Together, Quadratic Equation and Inequality.

\section{PENDAHULUAN}

Matematika merupakan salah satu mata pelajaran yang dipelajari siswa mulai dari jenjang Sekolah Dasar (SD) sampai pada jenjang Perguruan Tinggi (Tanujaya, Prahmana, dan Mumu, 2017). Meskipun matematika sudah dipelajari sejak tingkat SD, namun masih banyak siswa yang beranggapan bahwa matematika sebagai mata pelajaran yang sulit, tidak menyenangkan, bahkan momok yang menakutkan sehingga masih banyak siswa yang mengalami kesulitan-kesulitan dalam mengerjakan soal-soal matematika (Sundayana, 2014; Lee, et al. 2018). Hal tersebut disebabkan oleh berbagai masalah, salah satunya adalah pembelajaran masih berpusat pada guru.

Beberapa faktor yang membuat siswa kurang aktif dan kurang mampu berinteraksi dengan siswa lain yaitu karena adanya perbedaan agama, latar belakang, suku dan budaya. Berdasarkan hal tersebut, upaya guru dalam meningkatkan keaktifan belajar siswa sangatlah penting. Salah satu usaha yang dapat dilakukan guru adalah merencanakan dan menggunakan model pembelajaran yang dapat mengkondisikan 
siswa agar belajar secara aktif dan dapat berinteraksi dengan siswa yang lain. Salah satu model pembelajaran yang dapat digunakan guru adalah model pembelajaran kooperatif (Rusman, 2011; Lee, et al. 2018).

Model pembelajaran kooperatif tipe NHT merupakan model pembelajaran yang sangat efektif untuk meningkatkan interaksi antara siswa yang berbeda agama, latar belakang, suku dan budaya, siswa lebih aktif dalam belajar, siswa lebih merasa bertanggung jawab dengan penomoran yang sudah diberikan. Dengan menggunakan model pembelajaran kooperatif tipe NHT diharapkan siswa dapat terlibat secara aktif dalam proses pembelajaran, saling membagi ide/gagasan dalam menyelesaikan tugas kelompok, mendapatkan pengalaman langsung dan dapat membangun sendiri pengetahuannya, sehingga dapat meningkatkan hasil belajar siswa dalam pembelajaran matematika (Rusman, 2011).

Berdasarkan hasil Observasi dan wawancara awal yang dilakukan di SMA Negeri 2 Manokwari, proses pembelajaran matematika khususnya pada pokok bahasan persamaan dan pertidaksamaan kuadrat masih menggunakan metode ceramah. Tidak menutup kemungkinan bahwa hasil tes atau nilai yang diperoleh siswa bergantung pada cara mengajar guru dan metode yang digunakan oleh guru sendiri. Dalam hal ini penyampaian materi, guru selalu menggunakan metode ceramah sehingga banyak siswa yang sulit memahami materi yang disampaikan. Dalam wawancara juga disimpulkan salah satu penyebab rendahnya hasil belajar siswa yaitu guru terlalu cepat dalam menerangkan materi pelajaran, penggunaan metode pengajaran dan pemilihan media kurang tepat, sehingga siswa kurang memahami materi, akibatnya nilai yang diperoleh siswa cenderung rendah. Siswa dikatakan tuntas belajar jika KKM (kriteria ketuntasan minimal) mencapai $\geq 65$. Tetapi pada kenyataannya, masih 70,59\% siswa yang belum tuntas atau belum mencapai KKM. Hal ini menjadi gambaran bahwa guru sebagai orang yang paling bertanggung jawab atas pelaksanaan pembelajaran di dalam kelas belum berhasil secara maksimal dalam melaksanakan KBM.

Matematika merupakan disiplin ilmu yang mempunyai sifat yang khas jika dibandingkan dengan disiplin ilmu yang lain dan matematika berkenaan dengan ide-ide atau konsep-konsep abstrak yang tersusun secara hierarki dan penalarannya deduktif. Menurut Depdiknas (2000), karakteristik matematika sendiri antara lain: memiliki objek kajian abstrak, bertumpu pada kesepakatan, berpola piker deduktif, memiliki simbol 
yang kosong dari arti, memperhatikan semesta pembicaraan. Dengan karakter tersebut proses pembelajaran matematika tentu saja membutuhkan model, metode dan pendekatan yang sesuai agar tujuan pembelajaran dapat tercapai dengan baik. Model pembelajaran kooperatif merupakan suatu model pembelajaran yang mengutamakan kerja sama antara siswa untuk mencapai tujuan pembelajaran, sedangkan menurut Tanujaya dan Mumu (2016) pembelajaran kooperatif merupakan pembelajaran yang mengutamakan kerjasama antar siswa untuk mencapai tujuan pembelajaran. Pembelajaran kooperatif merupakan suatu model pembelajaran dimana pata siswa dikondisikan untuk bekerja Bersama-sama di dalam suatu kelompok yang dibentuk. Tujuan pengelompokan adalah agar siswa dapat saling membantu satu sama lain dalam belajar. Terdapat beberapa tipe dalam model pembelajaran kooperatif, antara lain: tipe Student Teams Achievement Division (STAD), tipe Jigsaw, tipe Teams Games Tournament (TGT), tipe Think Pair Share (TPS), dan Numbered Heads Together (NHT). Masing-masing tipe model pembelajaran kooperatif tersebut, mempunyai kontribusi yang maksimal apabila diterapkan pada materi pelajaran dan karakteristik tertentu.

Model pembelajaran kooperatif mempunyai dasar yang tidak berubah, namun ada unsur-unsur dasar pembelajaran kooperatif yang membedakannya dengan pembagian kelompok yang dilakukan asal-asalan (Suprijono, 2009). Salah satunya adalah Numbered Heads Together (NHT). Pembelajaran kooperatif tipe Numbered Heads Together (NHT) dikembangkan oleh Spencer Kagan pada tahun 1992. Pembelajaran kooperatif tipe NHT merupakan salah satu tipe pembelajaran kooperatif yang menekan pada struktur khusus yang dirancang untuk mempengaruhi pola interaksi siswa dan memiliki tujuan untuk meningkatkan penguasaan akademik. Tipe ini dikembangkan oleh Kagan dengan melibatkan para siswa dalam menelaah bahan yang tercakup dalam suatu pelajaran dan mengecek pemahaman mereka terhadap isi pelajaran tersebut. Struktur yang dikembangkan oleh Kagan ini menghendaki siswa belajar saling membantu dalam kelompok kecil dan lebih dicirikan oleh penghargaan individual. Ada struktur yang memiliki tujuan umum untuk meningkatkan penguasaan isi akademik dan ada pula struktur yang tujuannya untuk mengajarkan keterampilan sosial (Ibrahim 2000). Model pembelajaran kooperatif tipe NHT adalah bagian dari model pembelajaran kooperatif struktural, yang menekankan pada sruktur-struktur khusus 
dirancang untuk mempengaruhi pola interaksi siswa.

Pembelajaran kooperatif tipe NHT yang dikembangkan oleh kagan (Ibrahim 2000), merupakan salah satu tipe pembelajaran kooperatif yang menekan pada struktur khusus yang dirancang untuk mempengaruhi pola interaksi siswa dan memiliki tujuan untuk meningkatkan penguasaan akademik. Pada Tipe ini, para siswa menelaah bahan yang tercakup dalam suatu pelajaran dan mengecek pemahaman mereka terhadap isi pelajaran tersebut. Struktur yang dikembangkan oleh Kagan ini menghendaki siswa belajar saling membantu dalam kelompok kecil dan lebih dicirikan oleh penghargaan individual.

Terdapat 6 (enam) langkah dalam pelaksanaan model Kooperatif tope NHT. Pertama-tama, guru mempersiapkan rancangan pelajaran dengan membuat Skenario Pembelajaran (SP), Lembar Kerja Siswa (LKS) yang sesuai dengan model pembelajaran kooperatif tipe NHT. Pada tahap kedua, dilakukan pembentukan kelompok. Pembentukan kelompok disesuaikan dengan model pembelajaran kooperatif tipe NHT. Guru membagi para siswa menjadi beberapa kelompok yang beranggotakan 3-5 orang siswa yang heterogen. Guru memberi nomor kepada setiap siswa dalam kelompok dan nama kelompok yang berbeda. Kelompok yang dibentuk merupakan percampuran yang ditinjau dari latar belakang sosial, suku dan budaya, jenis kelamin dan kemampuan belajar. Selain itu, dalam pembentukan kelompok digunakan nilai tes awal (pre-test) sebagai dasar dalam menentukan masing-masing kelompok.

Tahap selanjutnya, setiap kelompok harus memiliki buku paket atau buku panduan. Dalam pembentukan kelompok, tiap kelompok harus memiliki buku paket atau buku panduan agar memudahkan siswa dalam menyelesaikan LKS atau masalah yang diberikan oleh guru. Pada tahap ke empat, dilakukan diskusi tentang permasalahan pembelajaran. Dalam kerja kelompok, guru membagikan LKS kepada setiap siswa sebagai bahan yang akan dipelajari. Dalam kerja kelompok setiap siswa berpikir bersama untuk menggambarkan dan meyakinkan bahwa tiap orang mengetahui jawaban dari pertanyaan yang telah ada dalam LKS atau pertanyaan yang telah diberikan oleh guru. Pertanyaan dapat bervariasi, dari yang bersifat spesifik sampai yang bersifat umum.

Pada tahap terakhir, guru menyebut satu nomor dan para siswa dari tiap kelompok dengan nomor yang sama mengangkat tangan dan menyiapkan jawaban kepada siswa di 
kelas. Nomor yang sudah ditunjuk oleh guru akan menjelaskan hasil diskusi kelompoknya dan kemuadian nomor yang sama dari masing-masing kelompok akan menanggapi terlebih dahulu. Akhirnya guru bersama siswa menyimpulkan jawaban akhir dari semua pertanyaan yang berhubungan dengan materi yang disajikan.

NHT dapat meningkatkan pemahaman dan hasil belajar siswa, selain itu Kreatifitas murid termotivasi dan wawasan murid berkembang, karena mereka harus mencari informasi dari berbagai sumber. Guru tidak lagi sebagai satu-satunya sumber pembelajaran (teacher oriented), tetapi justru siswa dituntut untuk dapat menemukan dan memahami konsep-konsep baru (student oriented).

\section{METODE PENELITIAN}

Penelitian ini merupakan penelitian tindakan kelas (Classroom Action Research). Penelitian tindakan kelas adalah penelitian yang bertujuan untuk memperbaiki dan meningkatkan mutu teori dan praktik suatu pembelajaran yang dilakukan di kelas (Tanujaya dan Mumu, 2016). Oleh karena itu, penelitian ini bertujuan untuk meningkatkan hasil belajar matematika pokok bahasan persamaan dan pertidaksamaan kuadrat dengan melalui penerapan model pembelajaran kooperatif tipe NHT. Hasil belajar merupakan nilai berupa hasil tes siswa yang dilakukan di tiap siklus. Hasil belajar adalah ekspresi kemampuan kognitif sebagai respon terhadap permasalahan tertulis atau tidak tertulis (DePorter dan Hernacki, 1999).

Subjek dan sekaligus objek dalam penelitian ini adalah seluruh siswa kelas X-8 SMA Negeri 2 Manokwari yang berlokasi di Jalan Pertanian Wosi, Manokwari Provinsi Papua Barat. Penelitian dilaksanakan pada bulan November (semester I/semester ganjil) Tahun Ajaran 2015/2016, dengan jumlah siswa sebanyak 34 orang. Penelitian ini dilakukan dalam 3 siklus, dimana setiap siklus terdiri dari: (1) perencanaan (planning), (2) tindakan (acting) dan pengamatan (observing), dan (3) refleksi (reflecting).

Dalam penelitian ini, peneliti memilih model penelitian tindakan yang dikembangkan oleh KemmisTaggart, karena dalam pengambilan data, tindakan (acting) dan pengamatan (observing) dilakukan secara bersamaan. Adapun langkah-langkah model Kemmis dan Mc Taggart yang dilakukan dalam penelitian ini meliputi:

- Perencanaan. Pada tahap perencanaan yang perlu dilaksanakan terlebih dahulu adalah membuat rencana pelaksanaan pembelajaran (RPP), mempersiapkan fasilitas 
dari sarana pendukung yang diperlukan pada saat kegiatan belajar mengajar berlangsung, mempersiapkan instrumen untuk mendokumentasikan dan menganalisis data mengenai proses dan hasil belajar.

- Tindakan dan Pengamatan. Pada tahap ini peneliti melakukan tindakan yang telah dirumuskan dalam RPP dalam situasi yang aktual, yang meliputi kegiatan awal, inti, dan penutup. Tindakan yang dilakukan guna untuk memperbaiki dan meningkatkan kualitas pembelajaran. Pada saat tindakan dilakukan, secara bersamaan guru/peneliti melakukan kegiatan observasi. Observasi yang harus dilakukan adalah mengamati perilaku siswa yang sedang melakukan kegiatan belajar mengajar, memantau kegiatan diskusi atau kerja sama antara kelompok dan mengamati pemahaman masing-masing siswa dalam penguasaan materi pembelajaran dengan menggunakan instrumen berupa lembar observasi.

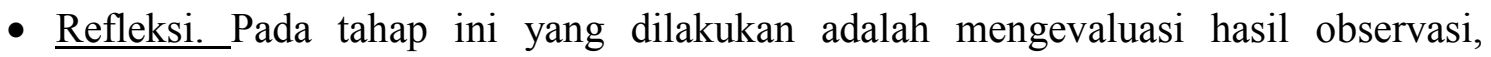
menganalisis hasil pembelajaran, dan mencatat kelemahan-kelemahan yang ada pada kegiatan belajar mengajar untuk dijadikan bahan penyusunan rancangan siklus berikutnya sampai tujuan PTK tercapai.

Dalam penelitian ini teknik dan instrumen pengumpulan data yang digunakan adalah tes, observasi, dan wawancara. Tes dalam penelitian ini dilakukan di setiap siklus pada akhir pembelajaran yang bertujuan untuk mengetahui pemahaman siswa terhadap materi yang diajarkan dengan menggunakan model koperatif tipe NHT. Observasi dilakukan selama proses pembelajaran, baik itu siswa maupun guru, sedangkan wawancara dilakukan untuk menguatkan kesimpulan berdasarkan hasil tes dan observasi. Hal ini sesuai dengan pendapat Tanujaya dan Mumu (2016), yang menyatakan bahwa dalam penelitian tindakan kelas, perlu dilakukan proses triangulasi agar data yang dihasilkan mempunyai validitas yang baik. Triangulasi adalah Teknik pemeriksaan keabsahan data yang memanfaatkan sesuatu yang lain di luar data itu untuk keperluan pengecekan atau pembanding terhadap data itu. Triangulasi dapat dilakukan dalam beberapa aspek, seperti dalam aspek metode, waktu, tempat, sumber data, peneliti, dan teori. Dalam penelitian ini dilakukan triangulai metode dan sumber data.

Data yang diperoleh yaitu hasil kuis (ulangan harian) siswa diakhir pembelajaran pada setiap siklus, dianalisis untuk menentukan nilai hasil belajar yang diperoleh siswa, 
dihitung dengan menggunakan rumus:

$$
\text { Nilai Rata-rata }=\frac{\text { Jumlah skor benar }}{\text { skor maksimal }} \times 100
$$

Sedangkan kriteria ketuntasan siswa Kelas X SMA Negeri 2 Manokwari untuk Mata Pelajaran Matematika adalah $\geq 65$.

\section{HASIL DAN PEMBAHASAN}

Langkah awal dalam penelitian sebelum melaksanakan tindakan peneliti mengadakan pretest untuk mengetahui sejauh mana hasil belajar siswa pada materi persamaan dan pertidaksamaan kuadrat. Hasil pretest menunjukan bahwa dari 34 siswa kelas X-8 SMA Negeri 2 Manokwari terdapat 18 siswa yang tidak tuntas.

Berdasarkan nilai pretest maka peneliti dan guru mata pelajaran matematika kelas $\mathrm{X}$ membagi siswa kedalam tujuh (7) kelompok yang heterogen, satu kelompok terdiri dari 4-5 siswa. Setiap kelompok mempunyai ketua kelompok yang bertugas untuk mengarahkan masing-masing anggota kelompoknya. Siswa yang mempunyai prestasi akademik tinggi dalam kelompok bertugas untuk membimbing dan memotivasi teman kelompoknya yang mempunyai prestasi akademik sedang dan rendah, karena nilai individu sangat berpengaruh terhadap nilai kelompok.

Tindakan siklus pertama dilaksanakan dalam dua kali pertemuan, dimana masingmasing pertemuan dengan alokasi waktu selama 45 menit. Pengamatan (observation) dilakukan pada siswa dan guru. Hasil observasi tentang keaktifan siswa pada siklus pertama, tampak bahwa masih banyak siswa yang belum melaksanakan KBM sesuai dengan yang diharapkan. Terdapat 6 (enam) aspek yang belum dilaksanakan dengan baik oleh siswa yaitu: siswa belum menanyakan hal-hal yang kurang jelas kepada guru, siswa belum melakukan diskusi aktif dengan kelompoknya, siswa belum mencoba mengemukakan pendapat sendiri mengenai apa yang dipikirkannya, siswa belum berani dan aktif dalam kelompok, siswa belum dapat menyelesaikan LKS-Kelompok dengan tepat waktu, dan siswa belum mampu menjawab pertanyaan dengan tepat dan benar.

Hasil observasi penilaian aktivitas guru pada siklus pertama, tampak bahwa terdapat 2 (dua) aspek yang belum dilaksanakan oleh guru (peneliti), yaitu: guru belum mengajukan pertanyaan atau isu yang terkait dengan pelajaran dan siswa diberi waktu untuk memikirkan pertanyaan tersebut secara mandiri, dan guru tidak memberikan tindak lanjut dan tidak memberi tugas kepada siswa untuk dikerjakan di rumah. 
Dari daftar nilai yang terdapat pada lampiran dapat diketahui bahwa nilai kuis individu siswa pada siklus pertama, sebagaimana disajikan pada Tabel 1.

Tabel 1. Sebaran Nilai Siswa pada Siklus Pertama

\begin{tabular}{lccl}
\hline No & Interval Nilai & Frekuensi & Kriteria \\
\hline 1 & $0-14$ & 15 & Belum Tuntas \\
2 & $15-24$ & 6 & Belum Tuntas \\
3 & $25-34$ & 2 & Belum Tuntas \\
4 & $35-44$ & 2 & Belum Tuntas \\
5 & $45-54$ & 5 & Belum Tuntas \\
6 & $55-64$ & 0 & Belum Tuntas \\
7 & $65-74$ & 3 & Tuntas \\
8 & $75-84$ & 1 & Tuntas \\
9 & $85-100$ & 0 & Tuntas \\
\hline
\end{tabular}

Berdasarkan Tabel 1, dapat dilihat bahwa pada siklus pertama sebanyak 4 orang yang tuntas yaitu sebesar 11,76\%, dan sebanyak 30 siswa tidak tuntas yaitu sebesar $88,24 \%$. Berdasarkan keseluruhan tindakan siklus pertama yang meliputi perencanaan, pelaksanaan dan pengamatan, maka dilakukan kegiatan refleksi. Peneliti bersama pengamat (observer), mendiskusikan hasil pelaksanaan tindakan dan pengamatan. Berdasarkan hasil analisis, hasil belajar matematika siswa pada siklus pertama diketahui jumlah total ketuntasan 11,76\% lebih rendah dari hasil pretest jumlah ketuntasan $47,06 \%$. Hasil observasi penilaian aktivitas guru pada siklus pertama pada pertemuan I dan II terdapat beberapa aspek yang belum dilaksanakan oleh guru (peneliti), yaitu: (1) guru belum mengajukan pertanyaan atau isu yang terkait dengan pelajaran dan siswa diberi waktu untuk memikirkan pertanyaan tersebut secara mandiri, dan (2) guru tidak memberikan tindak lanjut dan tidak memberi tugas kepada siswa untuk dikerjakan di rumah.

Hasil keaktifan siswa pada siklus pertama pertemuan I dan II terdapat beberapa aspek yang belum tercapai yaitu: (1) siswa belum menanyakan hal-hal yang kurang jelas kepada guru, (2) siswa belum melakukan diskusi aktif dengan kelompoknya, (3) siswa belum mencoba mengemukakan pendapat sendiri mengenai apa yang dipikirkannya, (4) siswa belum berani dan aktif dalam kelompok, (5) siswa belum dapat menyelesaikan LKS-Kelompok dengan tepat waktu, dan (6) siswa belum mampu menjawab pertanyaan dengan tepat dan benar. 
Pada siklus kedua, pembelajaran juda dilaksanakan dalam dua kali pertemuan. Pertemuan I dilaksanakan dengan alokasi waktu 2 x 45 menit (jam12.30 - 14.00 WIT). Pada pertemuan ini semua siswa kelas X-8 hadir yaitu 34 siswa, sedangkan pada pertemuan II, jumlah siswa yang hadir sebanyak 32 dari 34 siswa.

Pada tahap tindakan, pembelajaran dilaksanakan sesuai dengan Rencana Pelaksanaan Pembelajaran (RPP) yang telah disiapkan sebelumnya. Hasil observasi siswa, observasi guru, hasil tes dan perkembangan skor individu pertemuan I dan II siklus kedua akan dibahas lebih lanjut.

Hasil keaktifan siswa pada siklus kedua pertemuan I dan II dari 14 aspek yang dinilai, masih banyak siswa yang belum melaksanakan KBM sesuai dengan yang diharapkan dan rata-rata terdapat beberapa aspek yang belum tercapai serta dilaksanakan oleh siswa yaitu: (1) siswa belum mencoba mengemukakan pendapat sendiri mengenai apa yang dipikirkannya, (2) siswa belum berani dan aktif dalam kelompok, dan (3) siswa belum dapat menyelesaikan LKS-Kelompok dengan tepat waktu.

Hasil observasi penilaian aktivitas guru pada siklus kedua pertemuan I dan II dari 14 aspek yang dinilai masih terdapat beberapa aspek yang belum dilaksanakan oleh guru (peneliti) yaitu: guru belum mengajukan pertanyaan atau isu yang terkait dengan pelajaran dan siswa diberi waktu untuk memikirkan pertanyaan tersebut secara mandiri.

Dari tes yang diberikan dapat diketahui bahwa nilai kuis individu siswa pada siklus kedua seperti tampak pada Tabel 2.

Tabel 2. Sebaran Nilai Siswa pada Siklus Kedua

\begin{tabular}{lccl}
\hline No & Interval Nilai & Frekuensi & Kriteria \\
\hline 1 & $0-14$ & 3 & Belum Tuntas \\
2 & $15-24$ & 2 & Belum Tuntas \\
3 & $25-34$ & 4 & Belum Tuntas \\
4 & $35-44$ & 0 & Belum Tuntas \\
5 & $45-54$ & 5 & Belum Tuntas \\
6 & $55-64$ & 1 & Belum Tuntas \\
7 & $65-74$ & 12 & Tuntas \\
8 & $75-84$ & 3 & Tuntas \\
9 & $85-100$ & 4 & Tuntas \\
\hline
\end{tabular}


Berdasarkan Tabel 2, dapat dilihat bahwa pada siklus kedua sebanyak 19 orang siswa yang tuntas atau sebesar 55,88\% dari keseluruhan siswa, dan sebanyak 13 siswa tidak tuntas atau sebesar 44,12\%, dari keseluruhan siswa.

Berdasarkan keseluruhan tindakan siklus kedua yang meliputi perencanaan, pelaksanaan dan pengamatan maka dapat dilakukan hasil refleksi. Peneliti beserta observer mendiskusikan hasil pelaksanaan tindakan dan pengamatan yaitu hasil observasi. Berdasarkan hasil analisis hasil belajar matematika siswa pada siklus kedua diketahui jumlah total ketuntasan 55,88\% lebih tinggi dari hasil belajar matematika siswa pada siklus pertama, yaitu jumlah ketuntasan hanya 11,76\%.

Hasil observasi penilaian aktivitas guru pada siklus kedua pertemuan I dan II masih terdapat beberapa aspek yang belum dilaksanakan oleh guru (peneliti) yaitu : guru belum mengajukan pertanyaan atau isu yang terkait dengan pelajaran dan siswa diberi waktu untuk memikirkan pertanyaan tersebut secara mandiri. Hasil keaktifan siswa pada siklus I pertemuan I dan II juga masih terdapat beberapa aspek yang belum tercapai yaitu: (1) siswa belum mencoba mengemukakan pendapat sendiri mengenai apa yang dipikirkannya, (2) siswa belum berani dan aktif dalam kelompok, dan (3) siswa belum dapat menyelesaikan LKS-Kelompok dengan tepat waktu.

Selanjutnya, berdasarkan hasil refleksi pada siklus kedua, maka dilaksanakan tahap perencanaan tindakan ulang pada siklus ketiga. Tindakan siklus ketiga dilaksanakan dua kali pertemuan yang masing-masing pertemuan dengan alokasi waktu 2 x 45 menit). Hasil observasi penilaian keaktifan siswa pada siklus ketiga pertemuan I dan II secara keseluruhan sudah tercapai atau sudah terlaksana sesuai dengan aspek yang ada pada pedoman observasi tersebut. Hasil observasi penilaian keaktifan siswa pada siklus ketiga pertemuan I dan II juga terjadi perubahan,

Hasil observasi penilaian aktivitas guru pada siklus ketiga pertemuan I dan II secara keseluruhan sudah tercapai atau sudah terlaksana sesuai dengan aspek yang ada pada pedoman observasi tersebut. Hasil observasi menujukkan bahwa terjadi perubahan aktivitas guru dalam pembelajaran pada siklus ketiga pertemuan I dan II, demikian juga hasil tes yang diperoleh siswa. Hasil tes menunjukkan bahwa terjadi peningkatan persentase kelulusan siswa dibandingkan hasil yang diperoleh siswa pada siklus kedua. Nilai tes individu siswa pada siklus ketiga disajikan pada Tabel 3. 
Tabel 3. Sebaran Nilai Siswa pada Siklus Ketiga

\begin{tabular}{lccc}
\hline No & Interval Nilai & Frekuensi & Kriteria \\
\hline 1 & $0-14$ & 3 & Belum Tuntas \\
2 & $15-24$ & 0 & Belum Tuntas \\
3 & $25-34$ & 1 & Belum Tuntas \\
4 & $35-44$ & 0 & Belum Tuntas \\
5 & $45-54$ & 2 & Belum Tuntas \\
6 & $55-64$ & 0 & Belum Tuntas \\
7 & $65-74$ & 12 & Tuntas \\
8 & $75-84$ & 2 & Tuntas \\
9 & $85-100$ & 14 & Tuntas \\
\hline
\end{tabular}

Berdasarkan Tabel 3, dapat dilihat bahwa pada siklus ketiga, sebanyak 28 orang siswa yang tuntas atau sebesar $82,35 \%$, dan sebanyak 6 siswa tidak tuntas atau hanya sebesar 17,65\%. Hasil ini menunjukkan bahwa penerapan model Kooperatif tipe NHT dapat memperpaiki kualitas pembelajaran, yang berdampak langsung kepada kemampuan siswa dalam memahami materi pelajaran. Sedangkan berdasarkan hasil pada tindakan siklus ketiga yang meliputi perencanaan, pelaksanaan dan pengamatan maka dilakukan refleksi guna mengevaluasi pelaksanaan tindakan.

Peneliti dan observer, kemudian mendiskusikan hasil pelaksanaan tindakan dan pengamatan. Berdasarkan hasil analisis hasil belajar matematika siswa pada siklus ketiga diketahui jumlah total ketuntasan 82,35\% lebih tinggi dari hasil belajar matematika siswa pada siklus kedua yaitu jumlah ketuntasan hanya 55,88\%. Hasil observasi penilaian aktivitas guru dan keaktifan siswa pada siklus ketiga pertemuan I dan II secara keseluruhan sudah tercapai atau sudah terlaksana sesuai dengan aspek yang ada pada pedoman observasi tersebut.

Tindakan pada siklus ketiga yang diperbaiki berdasarkan hasil refleksi siklus kedua, yaitu siswa sudah bekerja sama dalam kelompok dan siswa yang mengalami kesulitan tidak langsung bertanya kepada peneliti tetapi bertanya kepada teman kelompoknya yang mempunyai kemampuan akademik lebih baik. Selain itu, peneliti memberikan penghargaan kelompok pada awal siklus ketiga yang membuat siswa lebih semangat dalam belajar dan adanya kekompakan kerja sama dalam kelompok. Hal ini dapat dilihat pada hasil tes individu siswa meningkat dari siklus sebelumnya.

Meningkatnya hasil tes setiap siswa menunjukkan bahwa setiap siswa dapat 
bekerjasama dengan siswa lain, terutama dalam aktifitas pembelajaran. Menurut Tanujaya dan Mumu (2016), dengan belajar bersama-sama, siswa diharapkan saling membantu untuk membentuk pemahamannya sendiri tentang suatu permasalahan dalam pembelajaran secara cepat, efisien, dan efektif.

Dengan demikian, pembelajaran kooperatif yang dilaksanakan dalam penelitian ini, merupakan model pembelajaran yang menganut paham konstruktivisme. Dalam teori konstruktivisme, tugas guru adalah memfasilitasi agar proses pembentukan (konstruksi) pengetahuan pada diri setiap siswa dapat terjadi secara optimal. Melalui hal tersebut, siswa akan lebih mudah menemukan dan memahami konsep-konsep yang sulit apabila mereka melakukan diskusi. Diskusi merupakan upaya yang efektif untuk meningkatkan keterampulan berpikir tingkat tinggi (HOTS) siswa. HOTS menurut Tanujaya (2016), Tanujaya, Mumu, dan Margono (2017), merupakan aspek penting yang menentukan keberhasilan siswa dalam pembelajaran. Siswa yang mempunyai HOTS yang cenderung mempunyai prestasi akademik yang lebih baik dibandingkan siswa yang mempunyai HOTS yang rendah.

\section{SIMPULAN}

Berdasarkan hasil penelitian dan pembahasan maka dapat disimpulkan bahwa penerapan model pembelajaran kooperatif tipe NHT dapat meningkatkan hasil belajar matematika siswa SMA pada pokok bahasan persamaan dan pertidaksamaan kuadrat. Peningkatan hasil belajar siswa tampak pada peningkatan nilai ketuntasan siswa di setiap siklus, setelah adanya perbaikan penerapan model pembelajaran kooperatif tipe NHT, melalui observasi dan refleksi. Perbaikan proses pembelajaran dilakukan pada aspek siswa maupun guru, secara timbal balik.

\section{DAFTAR RUJUKAN}

DePorter, B., \& Hernacki. (1999). Quantum Learning. Bandung: Kaifa Ibrahim, M. (2000). Pembelajaran Kooperatif. Surabaya: Unesa University Press.

Lee, C., Li, H. C., \& Shahrill, M. (2018). Utilising the Think-Pair-Share Technique in the Learning of Probability. International Journal on Emerging Mathematics Education, 2(1), 49-64.

Ngatini. (2012). Peningkatan Keaktifan dan Hasil Belajar Matematika Tentang Fungsi Melalui Model Pembelajaran Numbered Heads Together bagi siswa SMP. Jurnal Manajemen Pendidikan, 7(2), 151-159. 
Rusman (2011). Model-model Pembelajaran: Mengembangkan Profesionalisme Guru. Jakarta: Rajawali Pers.

Sanjaya, Wina. (2009). Penelitian Tindakan Kelas. Jakarta: Kencana Prenada Media Group.

Sriyati, S. M. (2013). Meningkatkan Aktivitas Dan Prestasi Belajar Siswa Dalam Pembelajaran Volume Kubus Dan Balok Melalui Penerapan Model Pembelajaran Kooperatif Tipe NHT Pada Siswa Kelas V SD. Skripsi, Denpasar: Universitas Mahasaraswati Denpasar.

Sundayana, R. (2014). Media dan Alat Peraga Dalam Pembelajaran Matematika. Bandung: Alfabeta.

Supriyono, A. (2009). Cooperative Learning: Teori dan Aplikasi PAIKEM. Yogyakarta: Pustaka Pelajar.

Syarfuni \& Suryati. (2014) Penerapan Model Pembelajaran Kooperatif Tipe Number Read Together (NHT) Untuk Meningkatkan Hasil Belajar Matematika Keliling Dan Luas Jajar Genjang Siswa Kelas IV SDN 32 Banda Aceh. Jurnal Tunas Bangsa, 1(1), 83-121.

Tanujaya, B. (2016). Development of an Instrument to Measure Higher Order Thinking Skills in Senior High School Mathematics Instruction. Journal of Education and Practice, 7(21), 144-148.

Tanujaya, B., \& Mumu, J. (2016). Penelitian Tindakan Kelas: Panduan Belajar, Mengajar, dan Meneliti. Yogyakarta: Media Akademi.

Tanujaya, B., Mumu, J, dan Margono, G. (2017). The Relationship between Higher Order Thinking Skills and Academic Performance of Student in Mathematics Instruction. International Education Studies, 10(11), 78-83.

Tanujaya, B., Prahmana, R. C. I, dan Mumu, J. (2017). Mathematics instruction, problems, challenges and opportunities: a case study in Manokwari Regency, Indonesia. World Transactions on Engineering and Technology Education, 15(3), 287-291.

Waeningsih. (2012). Peningkatan Pemahaman Tentang Penjumlahan Pecahan Berbagai Bentuk Melaui Penerapan Model Pembelajaran Kooperatif Tipe Numbered Heads Together (NHT). Jurnal Dinamika, 3(1), 100-104. 